(C) П.Я. Боднар, Я.Я. Боднар, Т.В. Боднар, Б.Д. Кривокульський, А.В. Левицький, 2020

\title{
Оцінка показників гемостазу у паціснток із флеботромбозом на фоні раку шийки матки
}

\author{
П.Я. Боднар ${ }^{1}$, Я.Я. Боднар ${ }^{2}$, Т.В. Боднар ${ }^{1}$, Б.Д. Кривокульський ${ }^{3}$, А.В. Левицький ${ }^{4}$ \\ ${ }^{I}$ Тернопільський національний медичний університет імені I. Я. Горбачевського, кафедра хірур- \\ гії № 1 з урологією, малоінвазивною хірургією та нейрохірургією імені професора Л. Я. Коваль- \\ чука, ${ }^{2}$ кафедра патологічної анатомії з секиійним курсом та судової медицини; \\ ${ }^{3}$ Тернопільський обласний клінічний онкологічний диспансер; \\ ${ }^{4}$ Медичний иентр «Медівіт», Тернопіль
}

\section{Реферат}

Вступ. Онкопатологія - одна 3 основних причин смертності населення, що спричиняє економічні втрати, пов'язані не тільки з вартістю лікування, але і з втратою здоров'я і інвалідністю населення працездатного віку. Рак шийки матки в даний час - одна 3 найбільш частих злоякісних пухлин жіночих статевих органів. Наявність флеботромбозів в онкологічних хворих достовірно впливає на тривалість життя, викликає триразове збільшення смертності у порівнянні з пацієнтами 3 поєднанням тромбозу 3 доброякісними захворюваннями. Найбільш поширеною причиною смерті госпіталізованих у стаціонар хворих $є$ тромбоз. Дослідження гемостазіологічних показників повинно враховуватися при визначенні тактики лікування онкологічних хворих.

Мета дослідження. Визначити закономірності зміни гемостазіологічних показників крові у хворих на рак шийки матки в залежності від гістологічного варіанту пухлини.

Матеріали та методи. Обстежено 28 жінок, які були розподілені на контрольну групу: 7 жінок соматично здорових та 12 пацієнток $з$ аденокарциномою шийки матки та 9 пацієнток 3 плоскоклітинним раком шийки матки для вивчення показників системи гемостазу, що знаходилися на стаціонарному лікуванні у гінекологічному відділенні Тернопільського обласного клінічного онкологічного диспансеру. У всіх пацієнток діагностовано гострий флеботромбоз підколінно-гомілкового сегмента.

Результати досліджень та їх обговорення. 3 представлених даних при порівнянні груп пацієнток з аденокарциномою шийки матки і плоскоклітинним раком шийки матки статистично достовірним виявилося зменшення тромбінового часу $(\mathrm{p}<0,01)$, активованого часткового тромбопластинового часу $(\mathrm{p}<0,005)$ i протромбінового часу ( $<0,005)$ що свідчить про гіперкоагуляцію. При аналізі фібриногену виявлено статистичне збільшення показників ( $<0,01)$, що свідчить про схильность до тромбоутворення з ризиком тромбоембологенних ускладень. Підвищені значення розчинних фібрин-мономерих комплексів (РФМК) (р<0,01), які є маркерами тромбінемії при внутрішньосудинному згортанні крові, свідчать про активацію згортальної системи крові. Також нами відзначено статистичний вплив морфологічної структури пухлини на показники згортальної ситеми. Так, рівень фібриногену $(\mathrm{p}<0,005)$, РФМК (р<0,005) більший у пацієнтів 3 аденокарциномою шийки матки порівняно 3 пацієнтами 3 плоскоклітинним раком шийки матки, також відзначено зменшення протромбінового та тромбінового часу, що свідчить про активацію згортальної системи крові.

Висновки. Встановлено достовірний вплив раку шийки матки на активацію згортальної системи крові. Виявлено залежність морфологічної структури раку шийки матки на розвиток тромбозу. Так, встановлено статистично більший прояв гіперкоагуляції у пацієнтів з аденокарциномою шийки матки в порівнянні з пацієнтами із плоскоклітинним раком шийки матки. Хворі з раком шийки матки відносяться до групи високого ризику розвитку тромбоемболічних ускладнень і потребують профілактики тромботичних ускладнень.

Ключові слова: рак шийки матки, тромбоз глибоких вен, згортальна система.

Evaluation of hemostasis in patients with vein tromobosis with cervical cancer Bodnar P.Ya. ${ }^{1}$, BodnarYa.Ya. ${ }^{2}$, Bodnar T.V. ${ }^{1}$, Kryvokulsky B.D. ${ }^{3}$, Levitsky A.V. ${ }^{4}$

${ }^{1}$ I. Horbachevsky Ternopil National Medical University, L.Ya. Kovalchuk Department of Surgery No.1, Urology, Minimally Invasive Surgery and Neurosurgery;

${ }^{2}$ Autopsy Course and ForensicP athology;

${ }^{3}$ Ternopil Regional Clinical Oncology Center;

${ }^{4}$ Medivit Medical Center, Ternopil

Introduction. Oncopathology is one of the main causes of mortality in the population, causing economic losses associated not only with the cost of treatment, but also with the loss of health and disability of the working age population. Cervical cancer is currently one of the most common malignant tumors of the female genital organs. The presence of phlebotrombosis in cancer patients significantly affects life expectancy, causing a three foldin crease in mortality compared with patients with a combination of thrombosis with benign diseases. The most common cause of death of hospitalized patients is thrombosis. The study of haemosthesiological parameters should be taken in to account when determining the tactics of treatment of cancer patients.

The aim of the study. Determination of patterns of changes in hemosthesiological parameters of blood in patients with cervical cancer, depending on the histological variant of the tumor.

Materials and methods. 28 women were allocated to the control group - 7 women with somatic healthy women and 12 patients with adenocarcinoma of the cervix and 9 patients with squamo uscell carcinoma of the cervix for in patient treatment 
in gynecological clinic oncology department . In all patients, acute phlebotrombosis of the popliteal and tibial segments was diagnosed.

Results of the studies and their discussion. From the presented data, when comparing groups of patients with adenocarcinoma of the cervix and squamo uscell carcinoma of the cervix, statistically significant decrease in thrombintime $(p<0.01)$, activated partial thromboplastin time $(p<0.005)$ and prothrombin time $(p<0.005)$ was found. In the analysis of fibrinogen, a statistically significan tincrease $(\mathrm{p}<0.01)$ was observed, indicating a tendency to thrombosis with the risk of thromboembolic complications. In creased values of soluble fibrin-monomer complexes ( $p<0.01)$, which are markers of thrombinemiainintra vascular coagulation, indicate activation of the coagulation system. We also noted the statistical influence of the morphological structure of the tumor on the indicators of the coagulation system. Thus, the level of fibrinogen ( $p$ $<0.005)$, soluble fibrin-monomer complexes $(\mathrm{p}<0.005)$ is higher in patients with adenocarcinoma of the cervix compared with patients with squamo uscell carcinoma of the cervix; bloodsystems.

Conclusions. Significant effect of cervical cancer on the activation of the coagulation system has been established. The dependence of the morphological structure of cervical cancer on the development of thrombosis was revealed. Thus, there was a statistically greater manifestation of hypercoagulation in patients with adenocarcinoma of the cervix compared to patients with squamo uscell carcinoma of the cervix. Patients with cervical cancer are at high risk for developing thromboembolic complications and need to prevent thrombotic complications.

Key words: cervical cancer, deep vein thrombosis, coagulation system

Вступ. Поєднання онкозахворювань та флеботромбозів все частіше викликає зацікавленість. Онкопатологія - одна з основних причин смертності населення, що провокує економічні втрати, пов'язані не тільки 3 вартістю лікування, але і 3 втратою здоров'я і інвалідністю населення працездатного віку $[1,2]$. Онкогінекологія посідає друге місце в структурі онкозахворюваності. Рак шийки матки в даний час - одна 3 найбільш частих злоякісних пухлин жіночих статевих органів. Щорічно в світі на рак шийки матки хворіють понад 500000 жінок. Близько 200000 жінок щороку вмирають від цього захворювання [3, 4, 5]. Пацієнти, хворіючи онкологічними захворюваннями знаходяться в групі ризику розвитку тромбозів, однак і хворі з тромбозом можуть мати не виявлену до моменту появи клінічних ознак тромбозу злоякісну пухлину $[6,7]$. Наявність флеботромбозів в онкологічних хворих достовірно впливає на тривалість життя, викликає триразове збільшення смертності у порівнянні 3 пацієнтами $з$ поєднанням тромбозу з доброякісними захворюваннями [8]. Найбільш поширеною причиною смерті госпіталізованих в стаціонар хворих $є$ тромбоз [9].

Для оцінки активності системи плазмового гемостазу застосовуються тести: активований частковий тромбопластиновий час (АЧТЧ), що показує час згортання по внутрішньому шляху (оцінюється активність факторів XII, XI, IX, VIII), протромбіновий час (ПТЧ), що оцінює час згортання по зовнішньому шляху згортання (фактори X, VII, V, II). Обидва описані шляхи згортання впливають на фібриноген через систему протромбіну, для оцінки активності якого використовується тромбіновий час (ТЧ); кількісна оцінка субстрату згортання (фібриногену) проводиться за методом Клауса. Розчинні фібрин-мономерні комплекси (РФМК) відображають активність тромбоутворення, є маркерами кількісного вмісту фібрину. Підвищення рівня ФМК в плазмі характерно для активації системи згортання крові, причому, чим більше їх концентрація, тим активніше процес внутрішньосудинного тромбоутворення. Для характеристики тромбоутворення використання вищевказаних показників дозволяє сформулювати кілька різних патогенетичних механізмів: прискорення часу згортання (АЧТЧ, ПТЧ, ТЧ) свідчить про гіперкоагуляцію, збільшення концентрації фібриногену про підвищений ризик тромбоутворення, збільшення ФМК дає оцінку активності процесу згортання та відображають системний вплив злоякісної пухлини на організм, є найважливішими прогностичними факторами і маркерами ефективності терапії. Дослідження цих параметрів повинно враховуватися при визначенні тактики лікування онкологічних хворих.

Мета дослідження. Визначення закономірностей зміни гемастезіологічних показників крові у хворих на рак шийки матки в залежності від гістологічної варіанту пухлини.

Матеріали та методи. Обстежено 28 жінок, які були розподілені на контрольну групу - 7 жінок соматично здорових жінок для вивчення показників системи гемостазу та 4 групи - пацієнтки, які були розподілені за стадіями захворювання раку матки, 6 пацієнток 3 I стадією, 6 пацієнток 3 II стадією, 5 пацієнток з III стадією і 4 пацієнтки з IV стадією раку шийки матки, що знаходилися на стаціонарному лікуванні у гінекологічному відділенні Тернопільського обласного клінічного онкологічного диспансеру. Також пацієнтки були поділені згідно з морфологічною структурою верифікованої пухлини: 12 пацієнток з аденокарциномою шийки матки (рис. 2) та 9 пацієнток 3 плоскоклітинним раком шийки матки (рис. 3).

У всіх пацієнток діагностовано гострий флеботромбоз підколінно-гомілкового сегмента. Діагноз тромбозу вен встановлювали на основі об'єктивного стану та аналізу результатів інструментальних методів дослідження: ультразвукового дуплексного сканування судин нижніх кінцівок (рис. 4). УЗД-дослідження проводили на УЗДсканері експертного класу SIMENS ACUSONS 2000.

Дослідження гемостазіологічного стану плазми крові включало визначення протромбінового часу за Квіком, протромбінового індексу, активованого часткового тромбопластинового часу, фібриногену 
А та фібрин-мономерного комплексу згідно 3 інструкцією до реактивів фірми RENAM (Німеччина).

Для гістологічного дослідження тканину фіксували в $10 \%$ забуференому розчині нейтрального формаліну. Депарафінізовані зрізи фарбували за стандартними методиками гематоксиліном і еозином. Світлооптичне і поляризаційне дослідження гістологічних препаратів здійснювали за допомогою тринокулярного мікроскопу з камерою програмної обробки зображень і поляризацією комерційної фірми SEO. Зображення 3 мікроскопа виводили на монітор комп'ютера за допомогою відеокамери «Vision Color CCD Camera».

Статистичний аналіз проводився 3 використанням програмного забезпечення Excel. Для статистичного аналізу і опису показників використовували середнє значення ознаки (M) \pm стандартне відхилення (м), для визначення статистичної значущості відмінностей - $\mathrm{t}$ критерій Стьюдента. Відмінності між порівнюваними параметрами вважали статистично значущими при $\mathrm{p} \leq 0,05$.

Результати досліджень та їх обговорення. Розподіл пацієнток залежно від стадії і гістологічного варіанту пухлини (рис. 1).

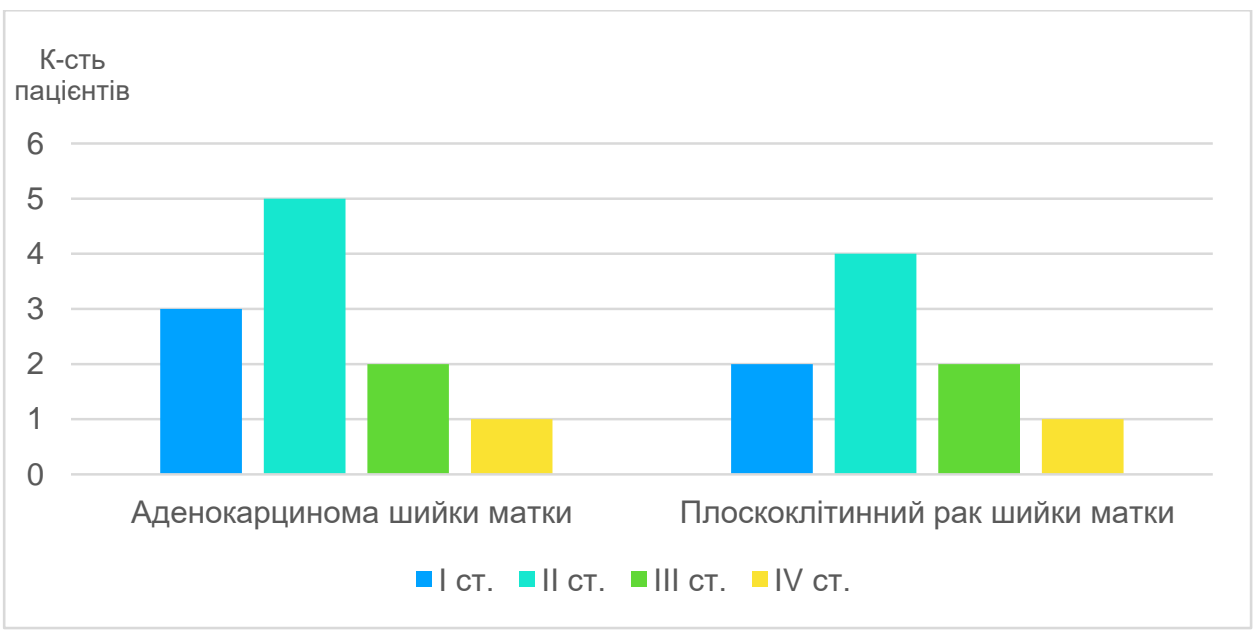

Рис. 1. Розподіл пацієнток залежно від стадії і гістологічного варіанту пухлини

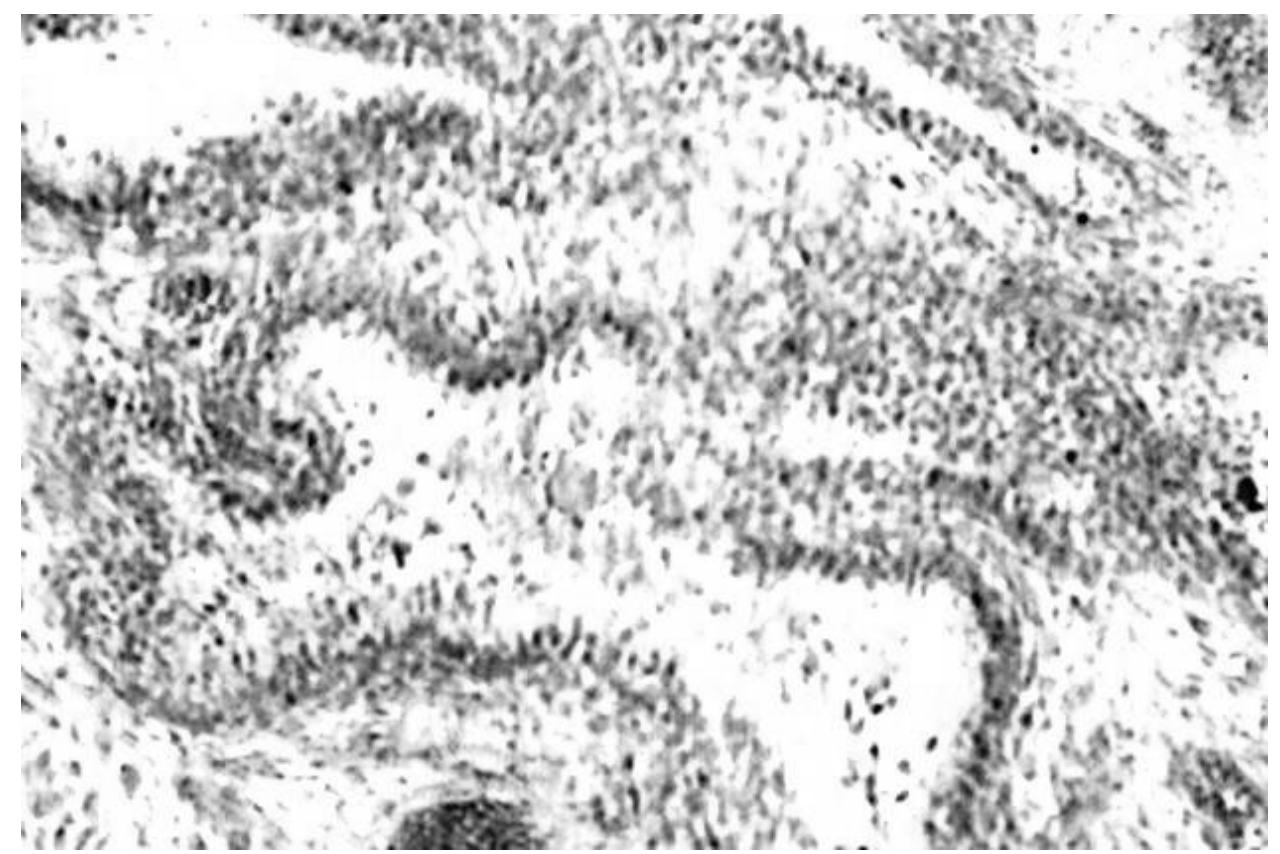

Рис. 2. Аденокарцинома матки G 2. Забарвлення гематоксиліном і еозином. X 120. 


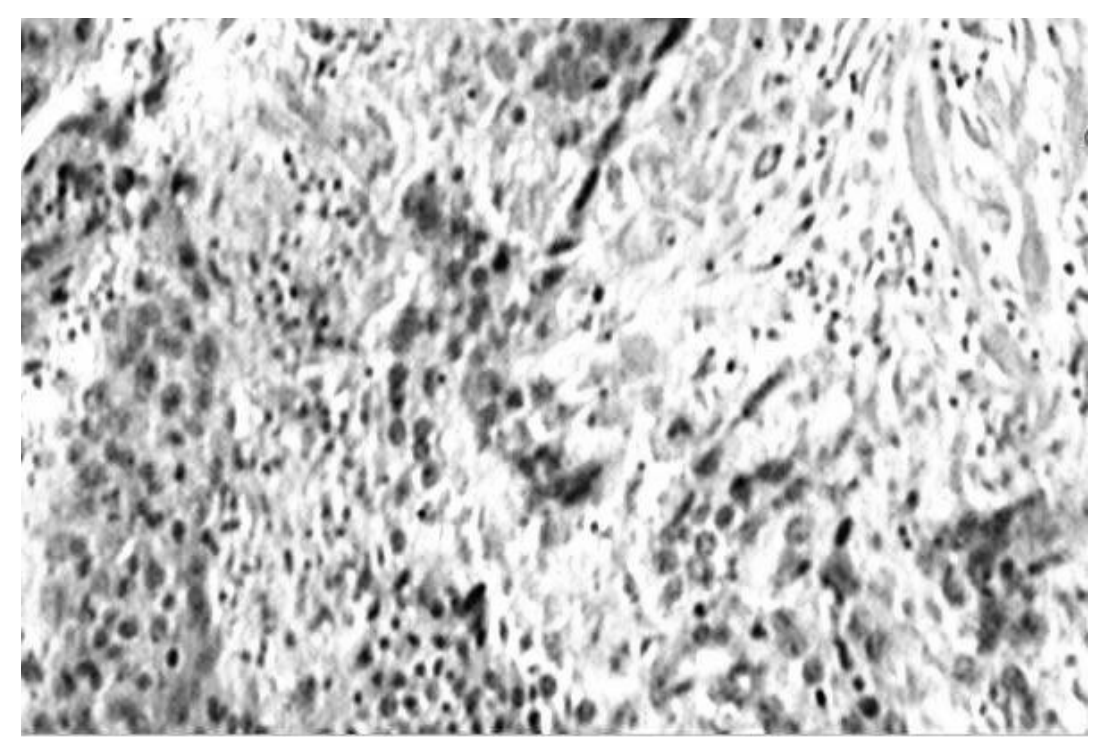

Рис. 3. Плоскоклітинний рак шийки матки G 3. Забарвлення гематоксиліном і еозином. X 240.

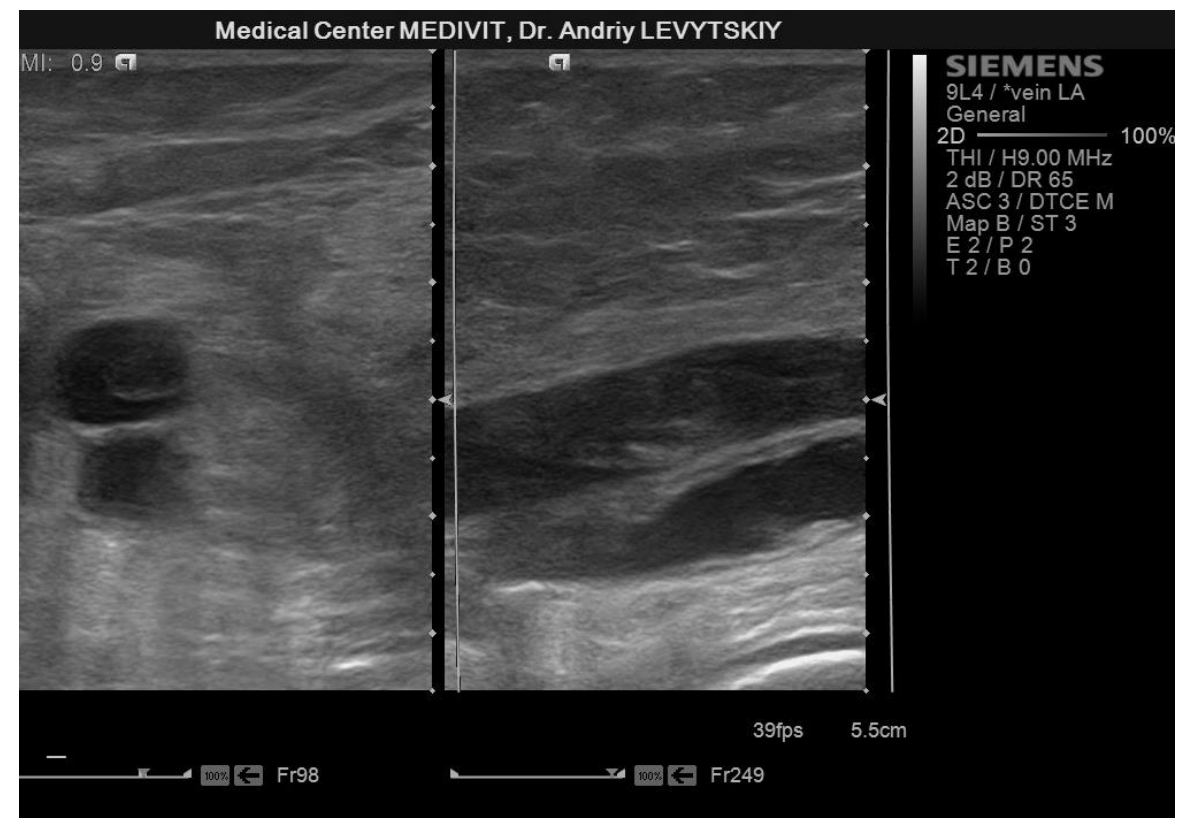

Рис. 4. Ультразвукове дослідження венозної системи. Тромбоз підколінної вени.

Зміни гемастозіологічних показників залежно від гістологічного варіанту пухлини представлено у таблиці 1.

Таблиця 1

Зміни гемастозіологічних показників в залежності від гістологічного варіанту пухлини

\begin{tabular}{|l|l|l|l|l|l|}
\hline \multicolumn{1}{|c|}{$\begin{array}{c}\text { Гістологічний } \\
\text { варіант/гемоста- } \\
\text { зіологічні показники }\end{array}$} & $\begin{array}{c}\text { РФМК, } \\
\text { мг/мкл }\end{array}$ & $\begin{array}{c}\text { Фибриноген, } \\
\text { г/л }\end{array}$ & $\begin{array}{c}\text { Тромбіновий час, } \\
\text { с }\end{array}$ & АЧТЧ, с & $\begin{array}{c}\text { Протромбі- } \\
\text { новий час, с }\end{array}$ \\
\hline $\begin{array}{l}\text { Контрольна група } \\
(\mathrm{n}=7)\end{array}$ & $3,6 \pm 1,2$ & $2,3 \pm 1,1$ & $11,5 \pm 3,5$ & $26,8 \pm 5,8$ & $16,5 \pm 4,1$ \\
\hline $\begin{array}{l}\text { Аденокарцинома шийки } \\
\text { матки } \\
(\mathrm{n}=12)\end{array}$ & $6,9 \pm 2,8$ & $8,9 \pm 1,6$ & $\begin{array}{l}7,5 \pm 1,2 \\
(\mathrm{p}<0,01)\end{array}$ & $21,1 \pm 2,1$ & $\begin{array}{l}9,2 \pm 2,6 \\
(\mathrm{p}<0,005)\end{array}$ \\
\hline $\begin{array}{l}\text { Плоскоклітинний рак } \\
\text { шийки } \\
(\mathrm{n}=9)\end{array}$ & $5,6 \pm 1,8$ & $7,2 \pm 1,4$ & $\begin{array}{l}8,4 \pm 1,7 \\
(\mathrm{p}<0,01)\end{array}$ & $21,6 \pm 2,3$ & $10,9 \pm 2,8$ \\
\hline
\end{tabular}


Iз представлених даних при порівнянні груп пацієнток 3 аденокарциномою шийки матки i плоскоклітинним раком шийки матки статистично достовірним виявилося зменшення ТЧ $(\mathrm{p}<0,01)$, АЧТЧ (p<0,005) і ПТЧ (p<0,005), що свідчить про гіперкоагуляцію. При аналізі фібриногену відзначено статистичне збільшення показників $(\mathrm{p}<0,01)$, що свідчить про схильність до тромбоутворення 3 ризиком тромбоембологенних ускладень. Підвищені значення РФМК (p<0,01), які $є$ маркерами тромбінемії при внутрішньосудинному згортанні крові, свідчать про активацію згортальної системи крові. Також нами виявлено статистичний вплив морфологічної структури пухлини на показники згортальної ситеми. Так, рівень фібриногену $(\mathrm{p}<0,005)$, РФМК $(\mathrm{p}<0,005)$ більший у пацієнтів 3 аденокарциномою шийки матки в порівнянні 3 пацієнтами 3 плоскоклітинним раком шийки матки, також виявлено зменшення протромбінового та тромбінового часу, що свідчить про активацію згортальної системи крові.

Висновки. 1. Встановлено достовірний вплив раку шийки матки на активацію згортальної системи крові.

2. Виявлено залежність морфологічної структури раку шийки матки на розвиток тромбозу. Так, встановлено статистично більший прояв гіперкоагуляції у пацієнтів 3 аденокарциномою шийки матки в порівнянні 3 пацієнтами із плоскоклітинним раком шийки матки.

3. Хворі з раком шийки матки відносяться до групи високого ризику розвитку тромбоемболічних ускладнень і потребують профілактики тромботичних ускладнень.

Інформація про конфлікт інтересів. Автори заявляють про відсутність конфлікту інтересів при виконанні наукового дослідження та підготовці даної статті.

Інформація про фінансування. Автори гарантують, що вони не отримували жодних винагород у будь-якій формі, здатних вплинути на результати роботи.

Особистий внесок кожного автора у виконання роботи:

Боднар П.Я. - розробка концепції і дизайну дослідження, аналіз отриманих даних, редагування, статистична обробка даних.

Боднар Я.Я. - збір матеріалу дослідження, розробка дизайну дослідження, аналіз отриманих даних, підготовка тексту статті.

Боднар Т.В. - збір матеріалу дослідження, аналіз отриманих даних, підготовка тексту статті.

Кривокульський Б.Д. - збір матеріалу дослідження, аналіз отриманих даних, підготовка тексту статті. Левицький А.В. - збір матеріалу дослідження, аналіз отриманих даних.

\section{Список використаної літератури}

1. Vorobiova LI, HoncharukIV, LukianovaNI. Kliniko-morfolohichni ta molekuliarni-biolohichni faktoryprohnozu u khvorykhnarakshyikymatky / Onkolohyia. 2008. T.10, № 4. S. 382-388. [inUkrainian]

2. Karnabeda OA. Venoznaia tromboembolyia u patsyentov s onkopatolohyei Klynycheskaia onkolohiia. 2012. №5(1). S.109-114. [InRussian].

3. Kryvokulskyi BD, ZhulkevychI.V. Ryzykadaptovani pidkhody do profilaktyky trombotychnykh uskladnen pry histerektomii / Shpytalnakhirurhiia. Zhurnalimeni L. Ya. Kovalchuka. - 2018. - № 2 (82). - S. $78-83$. [inUkrainian]

4. MorkhovK.Iu. Aktualnue voprosu khyrurhycheskoho lechenyia raka sheiky matky / K.Iu. Morkhov, V.M. Nechushkyna, V.V. Kuznetsov // Prakt. onkolohyia.- 2009.- T.10.,№ 2.- S. 93-100. [InRussian].

5. Sukhina O.M. Porivnialnyi analiz efektyvnosti riznykh skhem kombinovanoho likuvannia khvorykh na rak shyiky matky / O.M. Sukhina, O.A. Mikhanovskyi, V.S. Sukhintain. // Promeneva diahnostyka, promene vaterapiia. - 2006. - № 2. - S. 71-75. [inUkrainian]

6. Rizzo JD., Brouwers M., Hurley P. etal. American Society of Hematology. American Society of Clinical Oncology clinical practice guide lineup date on the use of epoetinanddarbepoetinin adult patients with cancer. Blood. 2010; 116: 4045-4059.

7. AbadRico JL. Overview of venous thromboembolism / J. L. AbadRico, J. V. LlauPitarch, E. Rocha // Drugs. - 2010. - N 70, Suppl. 2. - P. 3-10.

8. Ludwig H., Van BS., Barrett-Lee P. etal. The European Cancer Anaemia Survey (ECAS): a large, multinational, prospective survey defining the prevalence, incidence, and treatment of anaemiain cancer patients. Eur $\mathrm{J}$ Cancer. 2004; 40: 2293-2306.

9. Caprini JA. Thromboticrisk assessment: A hybridapproach. - 2013. - Modeaccess : https://www.venousdisease.com /Publications/ JACaprini-HybridApproach3-10-05.pdf.

Стаття надійшла до редакції: 23.01.2020 р. 